\title{
Pelatihan Kewirausahaan Orang Tua Penyandang Disabilitas "Mitra Ananda" Kapanewon Nglipar, Kabupaten Gunung Kidul, Daerah Istimewa Yogyakarta
}

\author{
Frista $^{\# 1}$, The Maria Meiwati Widagdo ${ }^{* 2}$, Widya Christine Manus ${ }^{* 3}$, Matahari Bunga Indonesia*4

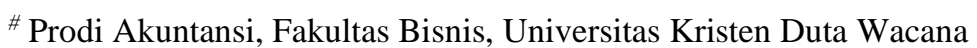 \\ Jalan dr. Wahidin Sudirohusodo No. 5-25, Yogyakarta \\ ${ }^{1}$ frista@staff.ukdw.ac.id \\ * Fakultas Kedokteran, Universitas Kristen Duta Wacana \\ Jalan dr. Wahidin Sudirohusodo No. 5-25, Yogyakarta \\ ${ }^{2}$ maria_widagdo@staff.ukdw.ac.id \\ 3 dr.widya.manus@staff.ukdw.ac.id \\ 441200471@students.ukdw.ac.id
}

\begin{abstract}
Abstrak-Merebaknya pandemi covid-19 telah menimbulkan dampak pada semua aspek kehidupan, bukan hanya dari sisi kesehatan namun juga telah mengganggu perekonomian, terutama menurunnya volume penjualan. Salah satu kelompok masyarakat yang terdampak oleh pandemi covid-19 adalah keluarga anggota organisasi Mitra Ananda yaitu organisasi orang tua dari anak-anak dengan disabilitas (cerebral palsy, autisme dan down syndrome) khususnya yang berbasis di Kabupaten Gunungkidul. Selama ini, Mitra Ananda telah menghasilkan produk kerajinan dari kain perca yang membuat "keset". Program ini dilaksanakan pada bulan Maret - Juli 2021 di Kabupaten Gunung Kidul, Daerah Istimewa Yogyakarta. Metode yang digunakan adalah pendampingan praktik pemasaran melalui platform digital dan pelatihan akuntansi dasar. Hasil dari pelatihan diharapkan Mitra Ananda dapat melakukan pemasaran dan pengelolaan keuangan dengan lebih baik.
\end{abstract}

Kata kunci-kewirausahaan, pemasaran daring, akuntansi dasar, covid-19, penyandang disabilitas..

Abstract - The outbreak of the COVID-19 pandemic has had an impact on all aspects of life, not only in terms of health but has also disrupted the economy, especially the decline in sales volume. One of the community groups affected by the COVID19 pandemic is the family of members of the Mitra Ananda organization, which is an organization for parents of children with disabilities (cerebral palsy, autism and down syndrome), especially those based in Gunungkidul Regency. So far, Mitra Ananda has produced handicraft products from patchwork that make "mats". This program will be held in March - July 2021 in Gunung Kidul Regency, Special Region of Yogyakarta.
The method used is mentoring marketing practices through digital platforms and basic accounting training. The results of the training are expected that Mitra Ananda can conduct marketing and financial management better.

Keywords - entrepreneurship, online marketing, basic accounting, covid-19, persons with disabilities.

\section{Pendahuluan}

Menurut Undang-Undang Nomor 8 Tahun 2016, penyandang disabilitas adalah setiap orang yang mengalami keterbatasan fisik, intelektual, mental, dan/atau sensorik dalam jangka waktu lama yang dalam berinteraksi dengan lingkungan dapat mengalami hambatan dan kesulitan untuk berpartisipasi secara penuh dan efektif dengan warga negara lainnya berdasarkan kesamaan hak (Indonesian President and Parliament, 2016). Undang-Undang Nomor 19 tahun 2011 tentang Pengesahan Konvensi mengenai Hak-hak Penyandang Disabilitas mengakui penyandang disabilitas sebagai bagian integral dari bangsa Indonesia yang tak terpisahkan dari anggota masyarakat lainnya. Jadi penyandang disabilitas memiliki kedudukan, hak dan kewajiban dan peran yang sama sebagai warga negara Indonesia.

Berdasarkan Profil Penduduk Indonesia tahun 2015 yang dikeluarkan oleh Badan Pusat Statistika terdapat 8,56\% penduduk Indonesia yang menyandang disabilitas (BPS, 2015). Kabupaten Gunungkidul memiliki populasi penyandang disabilitas tertinggi kedua setelah Sleman di 
Provinsi Daerah Istimewa Yogyakarta. Penyandang disabilitas di DIY pada tahun 2020 berjumlah total 8.333 orang dan 1.757 orang diantaranya merupakan penduduk di Gunungkidul (DIY, 2021).

Mitra Ananda adalah salah satu anak organisasi dari 19 organisasi yang berdiri dibawah lembaga pemberdayaan masyarakat yaitu Pusat Pemberdayaan Disabilitas Mitra Sejahtera (PPDMS) yang berlokasi di Desa Nglipar, Kabupaten Gunungkidul. Organisasi ini didirikan pada tanggal 18 Januari 2018, berdasar perasaan senasib sepenanggungan para cargiver yang terdiri dari orang tua ataupun pendamping anak dengan Cerebral Palsy. Kegiatan organisasi ini, mendukung kegiatan PPDMS. Saat ini jumlah anggota Mitra Ananda adalah 50 orang dan bertemu secara berkala dua bulan sekali.

Anak-anak dari anggota Organisasi Mitra Ananda menderita cerebral palsy, autisme dan Down Syndrome. Cerebral palsy adalah gangguan gerakan, otot, atau postur yang disebabkan oleh cedera atau perkembangan abnormal otak, dan paling sering terjadi pada waktu perkembangan janin dalam kandungan. Gangguan ini tidak bersifat progresif dan akan berubah seiring berjalannya waktu atau tumbuh kembang anak. Tanda yang sering muncul berupa kekakuan otot, refleks berlebihan, postur tubuh abnormal, gerakan tak terkendali, goyang atau tidak stabil saat berjalan. Selain gangguan motorik, orang dengan cerebral palsy juga bisa menderita disabilitas intelektual, masalah penglihatan, gangguan pendengaran dan wicara, atau kejang. Hal ini tergantung luasnya kerusakan dalam otak, jadi kondisi orang dengan cerebral palsy bisa berbeda satu dari yang lain, ada yang ringan dan ada yang berat sehingga sepenuhnya tergantung kepada orang lain dalam aktivitas sehari-hari.

Sebagian besar anak yang tergabung dalam Organisasi Mitra Ananda menderita cerebral palsy cukup berat, jadi orang tua harus membantu anak dalam banyak kegiatan sehari-hari. Autisme adalah kelainan perkembangan otak yang menyebabkan gangguan berkomunikasi dan bersosialisasi. Beratnya gangguan bervariasi dari ringan sampai berat. Down Syndrome adalah kelainan genetik yang menyebabkan penderita mempunyai intelektualitas di bawah rata-rata dan penampilan fisik yang khas. Keterbatasan yang dijumpai pada anak dengan autism atau down syndrome membuat mereka tergantung kepada orang lain dalam beberapa kegiatan sehari-hari.

Pandemi Covid-19 melanda dunia dimulai dengan ditemukannya kasus pertama di Tiongkok pada bulan Desember 2019 dan kemudian kasus pertama di Indonesia dikonfirmasi pada tanggal 2 Maret 2020 (WHO, 2020c)

\section{METODE PELAKSANAAN}

Pelatihan kewirausahaan bagi anggota Mitra Ananda dilakukan dalam tahap persiapan dan pelaksanaan, dengan detil kegiatan sebagai berikut.
(WHO, 2020b). Covid-19 disebabkan oleh virus corona yang dapat menyerang siapa saja tanpa kecuali. Penyakit ini dapat menyebabkan kerusakan seluruh organ tubuh, terutama pada sistem pernafasan (Mayo Clinic, 2020). Dampak covid-19 tidak sama pada tiap orang karena dipengaruhi oleh demografi atau kondisi orang itu, misalnya usia, adanya penyakit penyerta yang sering disebut komorbiditas, disabilitas, dan lain-lain. Jadi ada kelompok yang lebih rentan tertular dan bila tertular covid-19 mereka bisa jatuh sakit lebih berat daripada orang lain yang tidak mempunyai factor kerentanan. Virus ini amat mudah menular melalui udara. Jadi manusia harus mengembangkan kebiasaan baru untuk mencegah penularan seperti memakai masker, menjaga jarak, mencuci tangan dan menghindari kerumunan (WHO, 2020a). Edukasi perlu diberikan kepada setiap orang, termasuk penyandang disabilitas dan keluarga mereka.

Organisasi Mitra Ananda mengalami dampak dari pandemi covid-19 di bidang kesehatan dan ekonomi. Di bidang kesehatan, ada beberapa masalah yang dihadapi oleh Organisasi Mitra Ananda, seperti kehawatiran bila anak tertular covid-19, ketidaktahuan cara mencegah penularan, ketidaktahuan jalur rujukan pasien covid-19 dan ketidak tahuan isolasi mandiri bagi pasien positif covid-19 atau yang kontak erat dengan pasien positif covid-19. Orang tua merasa was-was terhadap kondisi anak mereka yang mempunyai keterbatasan, dan tidak tahu apa yang harus dilakukan. Orang tua sadar bahwa mereka harus mengembangkan kebiasaan baru untuk mencegah penularan covid-19, tetapi pelaksanaan kebiasaan baru pada penyandang disabilitas tidak mudah karena adanya keterbatasan yang membutuhkan modifikasi agar penyandang disabilitas tetap bisa terlindungi. Keluarga belum pernah mendapat edukasi tentang pencegahan covid19 pada anak-anak dengan cerebral palsy, autism atau Down syndrome.

Dampak bidang ekonomi yang dirasakan adalah penurunan daya beli akibat berkurangnya penghasilan keluarga. Setelah melakukan diskusi dengan mitra, disepakati bahwa fokus pemberdayaan untuk bidang ekonomi adalah penguatan kemampuan kewirausahaan dengan pelatihan digital marketing. Mitra Ananda telah menghasilkan sejumlah produk kerajinan tangan dari kain perca yaitu "keset" dengan beraneka ragam bentuk. Namun, pandemi covid-19 telah membuat pemasaran produk "keset" semakin sulit untuk dilakukan. Untuk produk kain perca yang dihasilkan oleh Mitra Ananda ditunjukkan pada contoh Gambar 1.

\section{A. Tahap Persiapan}

1) Pertemuan pertama. Pada tanggal 11 Januari 2021, dilakukan diskusi bersama anggota tim pengabdi membahas 
tujuan, apa yang ingin dicapai dan topik yang akan diangkat pada tanggal. Setelah itu, rapat bersama secara daring bersama ketua lembaga PPDMS pada tanggal 13 Januari 2021 untuk mengenal lebih dekat dengan anggota Mitra Ananda dilakukan sebagai langkah persiapan tahap pertama.

2) Pertemuan kedua. Pada tanggal 7 Februari 2021, pengabdi melakukan langkah persiapan tahap yang kedua yaitu dengan kunjungan dilakukan untuk mendapatkan

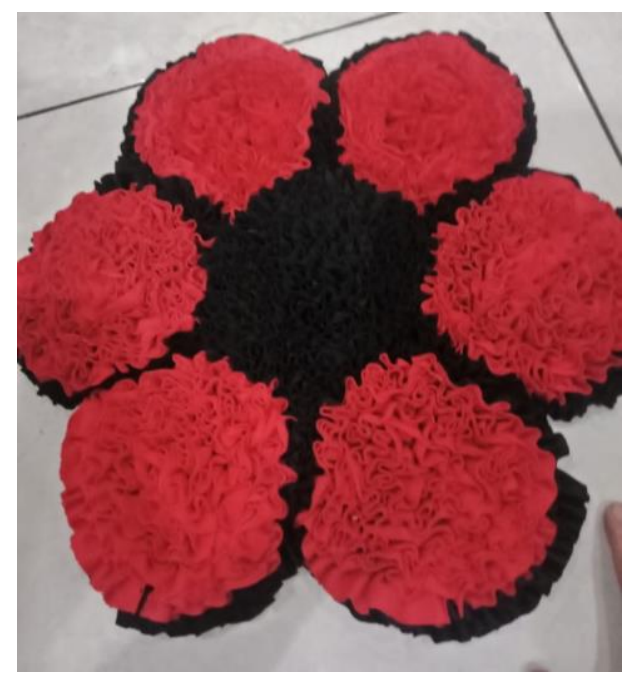

Gambar 1. Contoh produk kerajinan kain perca Mitra Ananda

informasi dan menilai kondisi nyata di lapangan dan mengamati situasi serta untuk menggali lebih lanjut kebutuhan dari anggota Mitra Ananda.

3) Pertemuan ketiga. Pada tanggal 15 Maret 2021, langkah persiapan tahap ketiga dilakukan pengabdi untuk mengatur jadwal, membagi tugas, mempersiapkan materi, berkas seperti presensi dan MoU serta mempersiapkan transportasi.

\section{B. Tahap Pelaksanaan}

Dilakukan pelaksanaan program pengabdian masyarakat dimulai dengan sosialisasi kepada anggota Pusat Pemberdayaan Disabilitas Mitra Sejahtera (PPDMS) dan Mitra Ananda yang hadir pada tanggal 3 April 2021 sebagaimana yang ditunjukkan dalam Gambar 2.

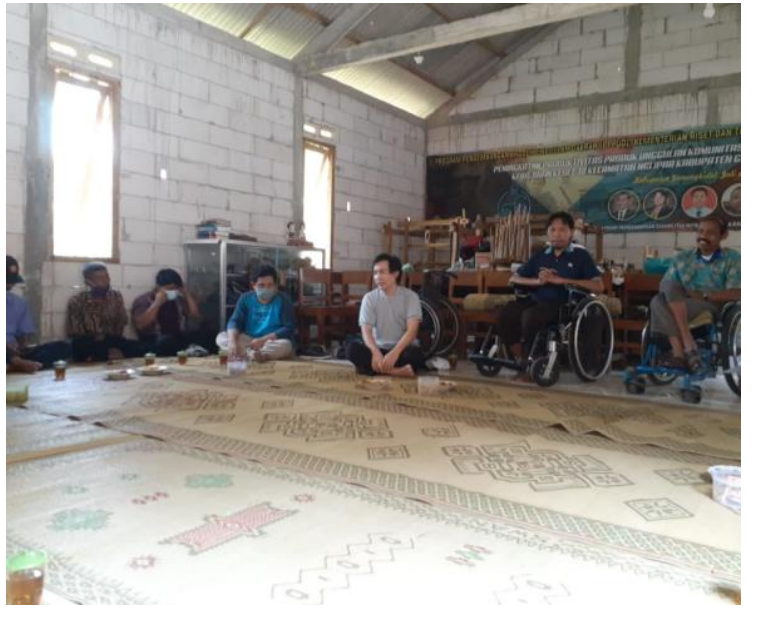

Gambar 2. Sosialisasi kegiatan

Untuk lebih rinci lagi, elemen yang hadir terdiri dari perwakilan sebagai berikut:

- Kelompok Pelita Kasih

- Kelompok Perawatan Diri (KPD) Ngawen

- Mitra Sejahtera, Nglipar.

- Mitra Handayani

- Mitra Mulia

- Mitra Sejati

- Kelompok Perawatan Diri (KPD) Mitra Manunggal

- Kelompok Perawatan Diri (KPD) Mitra Mandiri

- Sentra Sehati

- Mitra Ananda

Selanjutnya, pada tanggal 18 Mei 2021 dilakukan penyuluhan kewirausahaan dengan tema tentang pemasaran online dan pelatihan akuntansi dasar, sebagaimana yang ditunjukkan dalam Gambar 3.

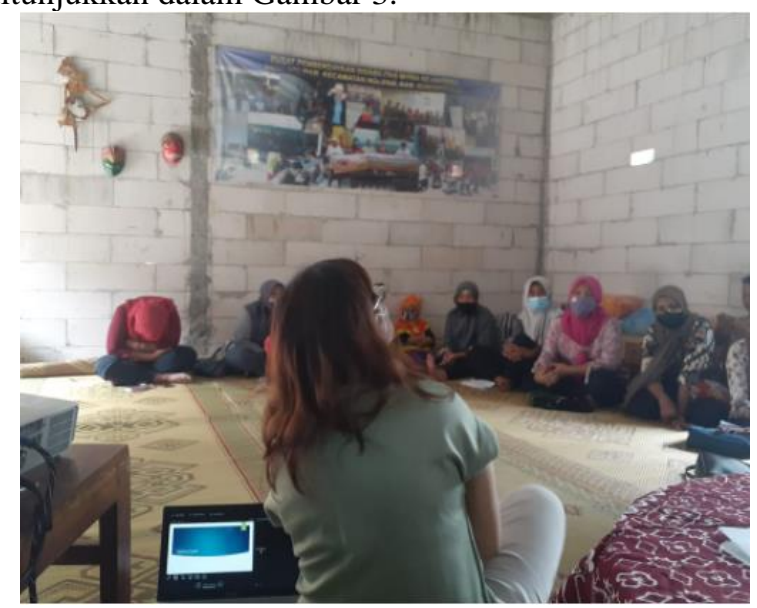

Gambar 3. Pelaksanaan Pelatihan 
Metode yang digunakan adalah kualitatif yakni berfokus pada diskusi dalam grup besar dengan meminta kesediaan anggota Mitra Ananda untuk mendiskusikan materi terkait.

\section{HASIL DAN PEMBAHASAN}

Menurut Suryana (2006) sumber peluang potensial bisnis dapat digali dengan cara :

1. Menciptakan produk baru yang berbeda.

Tahapan-tahapan penting dalam pengembangan produk baru yaitu: pemunculan ide, pemilihan ide, pengembangan konsep dan pengujian, strategi pemasaran, analisa bisnis, pengembangan produk, pengujian pasar, komersialisasi.

\section{Mengamati pintu peluang.}

Beberapa keadaan yang dapat menciptakan peluang, yaitu :

- Produk baru harus segera dipasarkan dalam jangka waktu yang relatif singkat.

- Kerugian teknik harus rendah

- Bila pesaing tidak begitu agresif untuk mengembangkan strategi produknya .

- Pesaing tidak memiliki teknologi canggih.

- Pesaing sejak awal tidak memiliki strategi dalam memperhatikan posisi pasarnya.

- Perusahaan baru memiliki kemampuan dan sumbersumber untuk menghasilkan produk barunya.

Selama ini, Mitra Ananda telah menghasilkan sejumlah produk kerajinan tangan dari kain perca yaitu "keset" dengan beraneka ragam bentuk. Berkaitan dengan pemasaran selama ini masih terbatas pada penjualan langsung yang terganggu sejak pandemic covid-19 terjadi. Dalam rangka memperluas pemasaran maka perlu dipertimbangkan untuk memanfaatkan teknologi informasi dan media pemasaran digital antara lain situs jejaring sosial seperti facebook dan twitter, dan platform e-commerce yang telah ada, harapannya produk ini akan semakin dikenal.

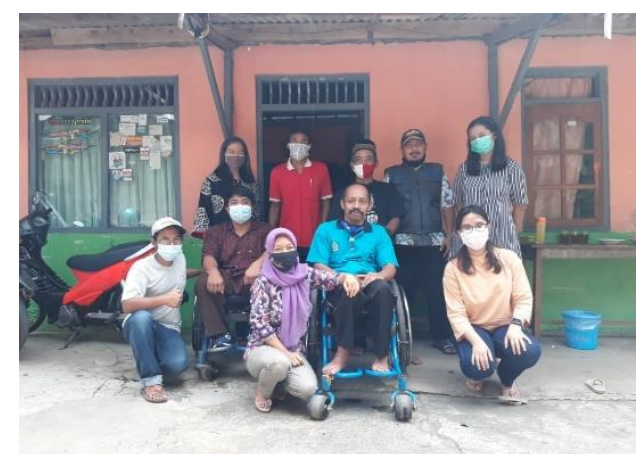

Gambar 4. Foto bersama, Pengabdi Bersama PPDMS - Mitra Ananda

Pelatihan kewirausahaan yang dilakukan kepada orang tua penyandang disabilitas "Mitra Ananda" difokuskan pada kegiatan pemasaran online dan pelatihan akuntansi dasar.

\section{A. Pemasaran online}

Merebaknya pandemi Covid-19 telah merubah tatanan dan proses bisnis yang ada. Para pelaku bisnis harus dapat menyesuaikan dan beradaptasi dengan pola kebiasaan baru yang lebih cenderung tergantung pada platform daring.

Satu hal yang disadari oleh para pengabdi bahwa tidak semua kalangan familiar atau terbiasa dengan penggunaan gawai apalagi untuk masyarakat di daerah terpencil seperti di Kabupaten Gunung Kidul. Oleh, karena ini terkait dengan kegiatan pelatihan pemasaran online ini, hanya difokuskan kepada para kader muda "Mitra Ananda".

Kalangan muda dari "Mitra Ananda" ini memang lebih cepat menangkap semua informasi yang disampaikan oleh para pengabdi terkait dengan kegiatan pemasaran online. Apalagi keberadaan aplikasi Tokopedia dan Shopee sudah sangat dikenal oleh kalangan tersebut. Mereka sangat antusias dengan pelatihan ini dan mengikuti dengan seksama semua proses dan tahapan yang dilatih.

Namun, rupanya kesulitan yang dihadapi mereka adalah bagaimana untuk dapat membuka aplikasi toko online, karena prosedur untuk melakukannya dirasakan sangat rinci dan sangat kompleks. Belum lagi dengan keterbatasan gawai yang mereka miliki yang masih memiliki spesifikasi yang rendah untuk resolusi kamera maupun memori yang terbatas. Di Kabupaten Gunung Kidul sendiri masih ditemukan kendala kesulitan terkait dengan sinyal di beberapa lokasi.

B. Akuntansi Dasar

Dalam menjalankan usaha tentu tidak terlepas dari bagaimana untuk mengelola dan menciptakan administrasi yang baik dan teratur. Untuk itu diperlukan adanya pengelolaan keuangan transparan dan akuntabel.

Pengabdi mengawali sesi ini dengan memberikan gambaran tentang pilihan bentuk/jenis usaha yang dapat dipilih dalam melakukan bisnis, antara lain: melalui pemilihan usaha perseorangan, perseroan komanditer, perseroan terbatas, dan koperasi.

Dari penjelasan terkait dengan koperasi, para peserta sangat tertarik dan merasa antusias dengan penjelasan terkait dengan koperasi. Ini karena saat ini, PPDMS sedang memperjuangan untuk pembentukan dan pengurusan perijinan terkait dengan Koperasi Simpan Pinjam. Dari diskusi yang dilakukan di sesi ini, baik pengabdi dan para peserta mendapatkan gambaran bahwa usulan pembentukan koperasi perlu diperluas menjadi Koperasi Serba Usaha (KSU) mengingatkan PPDMS dan 'Mitra Ananda" sudah memiliki unit bisnis yang mengelola usaha pembuatan kerajinan dari kain perca menjadi "keset".

Pelatihan akuntansi dasar dilakukan dengan memperkenalkan jenis-jenis akun, yang meliputi aset, hutang, modal, beban, dan pendapatan; saldo normal akun; jenis-jenis laporan keuangan: laporan laba rugi, laporan 
perubahan modal, laporan posisi keuangan, laporan arus kas. Para peserta diperkenalkan tentang apa saja kegunaan dari laporan keuangan tersebut.

Terkait dengan pelatihan akuntansi dasar, memang masih menjadi kesulitan bagi para peserta untuk memahami terkait dengan konsep dan tata cara melakukan penjurnalan

laporan keuangan ini akan sangat berguna pada saat Koperasi Serba Usaha (KSU) yang mereka sedang perjuangankan ini terbentuk.

Dari hasil diskusi yang dilakukan dengan peserta, pengabdi menemukan adanya kelemahan terkait dengan pengendalian terhadap kualitas maupun bagaimana untuk menghasil produk yang mampu dijual dengan harga yang bersaing. "Mitra Ananda" mengakui bahwa selama ini ada permasalah terkait dengan kualitas produk yang tidak seragam karena memang produk rumahan ini dikerjakan oleh anggota yang masing-masing memiliki kemampuan yang berbeda. Terkait dengan penentuan harga, ini terkendala dengan bahan baku kain perca yang mereka dapatkan dengan harga yang relatif tinggi sehingga mereka kesulitan untuk bersaingan sehubungan dengan penetapan harga.

Untuk kegiatan yang dapat dilakukan untuk pendampingan kepada "Mitra Ananda" dalam programprogram selanjutnya adalah lebih kepada aplikasi akuntansi biaya untuk bagaimana menghasilkan produk yang lebih efisien dan memiliki daya saing dari sisi harga jual.

Tentunya dalam kegiatan pengabdian masyarakat ini memiliki keterbatasan, seiring dengan meningkatnya kasus positif Covid-19. Mengikuti himbauan pemerintah yang memberlakukan Program Pembatasan Kegiatan Masyarakat (PPKM) yang mana Daerah Istimewa Yogyakarta menjadi salah satu daerah yang masuk dalam zona merah, terdapat pembatasan kegiatan sejak 3 Juli - 6 September 2021.

Ini juga yang membuat pengabdi kurang leluasa untuk melakukan kegiatan pendampingan lebih lanjut terkait dengan pemasaran online maupun akuntansi dasar. Salah satu strategi alternatif yang dilakukan adalah mengaktifkan grup WA. Keberadaan grup ini whatsapp, menjadi sarana untuk saling berkomunikasi, bertukar informasi, menyebarkan materi pelatihan yang lebih teknis, yaitu bagaimana untuk menggunakan aplikasi Tokopedia dan Shopee sebagai cara melakukan penjualan online di tengah masa pandemi. Ini menjadi salah satu cara untuk melakukan penjualan karena cara-cara yang konvensional tidak dimungkinkan untuk dilakukan. Terlebih saat ini, para anggota "Mitra Ananda" sudah ada yang memproduksi aneka makanan dan minuman, seperti jahe wangi. Artinya, peluang pemasaran digital ini dimungkinkan dengan menambah berbagai macam produk lain.

Dengan semakin banyak, mitra yang akan berkolaborasi dengan PPDMS maupun Mitra Ananda, semakin menuntut adanya pengelolaan bisnis yang lebih profesional. Artinya, gagasan untuk memperjuangan terwujudnya Koperasi akuntansi. Oleh karena itu, diperlukan beberapa pelatihan lanjutan untuk membuat supaya peserta lebih terampil dalam mengerjakan jurnal akuntansi sehingga mampu menghasilkan pelaporan keuangan. Tentunya kemampuan untuk menghasilkan

Serba Usaha (KSU) adalah sesuatu yang layak untuk diupayakan. Ini juga terkait dengan pengelolaan sumber daya manusia (SDM) yang harus semakin kompeten dan mumpuni. Artinya mulai sekarang harus sudah ada spesialisasi dari pihak "Mitra Ananda". Tidak semua anggota harus menghasilkan produk namun mulai sekarang harus ada anggota yang berperan sebagai staff pemasaran online, tenaga administrasi keuangan, tenaga yang memastikan pengendalian kualitas.

Hal yang menarik dari keberadaan PPDMS dan Mitra Ananda ini adalah sebuah transformasi dari sebuah Lembaga Sosial yang berupaya untuk memberdayakan masyarakat disabilitas untuk semakin percaya diri menjadi sebuah entitas bisnis yang diharapkan akan dikelola secara profesional melalui keberadaan Koperasi Serba Usaha (KSU). Hal ini membuktikan bahwa kegiatan pengabdian masyarakat ini mengandung aspek keberlanjutan (sustainable). Artinya, aktivitas yang dilakukan tidak bersifat temporal, namun membutuhkan pendampingan yang terus menerus, sampai keberadaan koperasi serba usaha yang akan diperjuangkan betul-betul bisa mandiri dalam melakukan aktivitas pengelolaan bisnis.

Pendekatan yang dilakukan harus bersifat partisipatif, yang mana masyarakat yang diajak untuk terlibat dalam kegiatan pengabdian masyarakat harus mempunyai perubahan paradigma menjadi warga yang berdaya dan harus mau mempelajari hal-hal baru yang dialihkan dari pengabdi kepada masyarakat. Dengan demikian, pada saat pengabdi melakukan pelatihan kepada para calon pelatih (training of trainer) di masa mendatang, selalu diingatkan bahwa merekalah yang nanti akan menjadi agen-agen perubahan.

Ini bukan sebuah hal yang mudah, untuk itu dibutuhkan sebuah kolaborasi termasuk peran dari akademisi dengan latar belakang lintas ilmu, salah satunya dalam kesempatan ini adalah kolaborasi antara bidang ilmu bisnis dan kedokteran. Untuk kedepannya tidak menutup kemungkinan untuk keterlibatan dari program-program studi yang lain. Dengan demikian, trans-disiplin menjadi sebuah kebutuhan dalam kegiatan pengabdian masyarakat.

\section{KESIMPULAN}

Kegiatan pengabdian masyarakat berupa kegiatan pelatihan kewirausahaan kepada orang tua penyandang disabilitas "Mitra Ananda" telah dilaksanakan dengan baik. Para peserta menyambut secara antusias kegiatan ini. Dari 
pelatihan ini diharapkan Mitra Ananda dapat melakukan pemasaran dan pengelolaan keuangan dengan lebih baik.

Program Pembatasan Kegiatan Masyarakat (PPKM) di Daerah Istimewa Yogyakarta menjadi salah satu daerah yang masuk dalam zona merah, terdapat pembatasan kegiatan sejak 3 Juli - 6 September 2021, menjadi kendala dalam kegiatan pengabdian masyarakat kali.

\section{UCAPAN TERIMA KASIH}

Ucapan terima kasih disampaikan kepada Lembaga Penelitian dan Pengabdian Masyarakat (LPPM) UKDW, Pusat Pemberdayaan Disabilitas Mitra Sejahtera (PPDMS) dan Mitra Ananda, Kabupaten Gunung Kidul. Tim pengabdi juga mengucapkan terima kasih yang sebesarbesarnya kepada Bapak Prayudi Utomo yang telah bersedia membagikan pengetahuan tentang digital marketing.

\section{DAFTAR PUSTAKA}

[1] Indonesian President and Parliament, Undang-Undang no.8 tahun 2016 tentang Penyandang Disabilitas, 2016.

[2] Indonesian President and Parliament, Undang-Undang Nomor 19 tahun 2011 tentang Pengesahan Konvensi mengenai Hak-hak Penyandang Disabilita, 2011.

[3] Badan Pusat Statistik, Profil Penduduk Indonesia, 2015.

[4] Biro Tata Pemerintahan Setda DIY. 2021. Statistik Penduduk D.I Yogyakarta. Jumlah Penduduk DI Yogyakarta Semester II 2020 Menurut Disabilitas. https://kependudukan.jogjaprov.go.id/statistik/penduduk/disabilitas/1 3/0/00/00/34.ez (Accessed: 28 Juni 2021)

[5] Mayo Clinic (2020) Coronavirus disease 2019 (COVID-19). Available at: https://www.mayoclinic.org/diseasesconditions/coronavirus/symptoms-causes/syc-20479963 (Accessed: 27 January 2021).

[6] WHO (2020a) Coronavirus disease (COVID-19) advice for the public Available at: https://www.who.int/emergencies/diseases/novelcoronavirus-2019/advice-for-public (Accessed: 27 January 2021).

[7] WHO (2020b) Coronavirus Disease 2019 (COVID-19)Situation Rep. Available at: https://www.who.int/docs/defaultsource/searo/indonesia/covid19/who-indonesia-situation-report1.pdf?sfvrsn=6be5b359_0 (Accessed: 27 January 2021).

[8] WHO (2020c) Listings of WHO's response to COVID-19. Available at: https://www.who.int/news/item/29-06-2020-covidtimeline (Accessed: 27 January 2021).

[9] Suryana, Kewirausahaan Pedoman Praktis: Kiat dan Proses Menuju. Sukses, Edisi Ketiga, Jakarta: Penerbit Salemba, 2006.

[10] P. Utomo, Digital Marketing: Pelatihan UKM Gedebage, 2021. 